\title{
Erken Çocukluk Dönemine Ait Resimli Çocuk Kitaplarında Cinsel Eğitim Unsurlarının İncelenmesi
}

\author{
Gökçen Merve ÖZTÜRK', Nihan FEYMAN GÖK²
}

\begin{abstract}
Öz: Cinsel eğitim, bireyin bütüncül gelişimini etkileyen ve olumlu değer yargıları geliştirmesini sağlayan bir eğitimdir. Ailelerin ve eğitimcilerin cinsel eğitim hakkında yeterli bilgilerinin olmaması çocukların cinsel eğitimden mahrum kalmasıyla sonuçlanmaktadır. Erken çocukluk döneminde başlaması gereken cinsel eğitim, ebeveynlerin ve öğretmenlerin sorumluluğundadır. Çocuklar doğal olarak vücutlarını merak ederler ve çocukların sorularını cevaplamak onların cinsel eğitim süreçlerinde önemli bir rol oynar. Resimli çocuk kitapları çocukların sorularını yanıtlamayı, onlarla açık ve dürüst bir iletişim kurmayı sağlayan önemli eğitim materyallerinden biridir. Hem aileler hem de öğretmenler, çocuklara cinsel eğitim unsurları içeren nitelikli resimli çocuk kitapları okuyarak cinsel eğitimi destekleyebilirler. Bu çalışmanın amacı, erken çocukluk dönemine yönelik olarak hazırlanmış resimli çocuk kitaplarının cinsel eğitim unsurları açısından incelenmesidir. Araştırma nitel yöntemlerinden durum çalışması ile desenlenmiş, veriler doküman incelemesi tekniği kullanılarak betimsel analiz ile çözümlenmiştir. Araştırmanın çalışma grubunu, amaçlı örnekleme yöntemiyle belirlenen 30 resimli çocuk kitabı oluşturmaktadır. Araştırmanın sonucunda, resimli çocuk kitaplarında cinsel eğitim unsurlarından en çok erkek-kadın vücutlarına, en az beden değerine yer verildiği görülmektedir. Araştırmadan elde edilen bulgulara göre resimli çocuk kitaplarında beden değerine daha çok yer verilmesi ve cinsel organların anatomik isimlerinin kullanılması önerilmektedir.
\end{abstract}

Anahtar Sözcükler: Cinsel eğitim, Erken çocukluk dönemi, Resimli çocuk kitabı

\section{Investigation of Sexuality Education Elements in Children's Picture Books for Early Childhood}

\begin{abstract}
Sexuality education is on which contributes to the holistic development of children and enables them to develop positive value judgments. Often, parents and educators may not have sufficient know ledge about sexuality education, resulting in children being deprived of necessary sexual information. Children are naturally curious about their bodies, and answering children's questions plays an important role in their sexual development. Thus, sexuality education, which should ideally begin in early childhood, is the responsibility of both parents and teachers. Children's picture books are an important educational material allowing parents to more easily answer their children's questions and to establish open and honest communication with them. Indeed, both parents and teachers can support sexuality education by utilizing quality children's picture books containing elements of sexuality education to children. The aim of this study is to examine children's picture books for early childhood in terms of sexuality education elements. The research was designed with case studies in qualitative research methods, the data were analyzed using content analysis and document examination techniques. The study group of the research consists of 30 children's picture books determined by the purposive sampling method. As a result of the study, it is seen that among the elements of sexuality education, there is sufficient representation of male/female bodies, however, body value is not sufficiently represented in the children's books examined. According to the findings obtained from the study, it is recommended that body value be included more prominently in children's picture books and that the proper anatomical names of the genitals be used.
\end{abstract}

Keywords: Sexuality education, Early childhood, Children's picture book

${ }^{1}$ Çankırı Karatekin Üniversitesi, Sağlık Bilimleri Fakültesi, Çocuk Gelişimi Ana Bilim Dalı, Çankırı, Türkiye, gokkceenozturkk@gmail.com, ORCID: https://orcid.org/0000-0003-2072-5714

2 Çankırı Karatekin Üniversitesi, Sağlık Bilimleri Fakültesi, Çocuk Gelişimi Ana Bilim Dalı, Çankırı, Türkiye, nihanfeyman@gmail.com, ORCID: https://orcid.org/0000-0002-0838-6791 
Erken çocukluk döneminin ilk altı yılı, çocuğun çevresel etmenlerden etkilendiği ve öğrenmenin çok hızlı olduğu kritik bir dönemdir. Cinsel eğitim, bu dönemde çocuğun desteklenmesi gereken alanlardan biridir. Yaşamın ilk yıllarında ailede temelleri atılan cinsel eğitim, okul ve diğer toplumsal faktörlerin katılımıyla toplumsal çevrede devam etmektedir (Çalışandemir, Bencik ve Artan, 2008).

Cinsel eğitim yalnızca biyolojik değil; cinsiyet kimlikleri, ilişkiler ve cinsiyet rolleri gibi psikolojik ve sosyal alanları da kapsamaktadır (World Health Organization, 2006). Cinsel eğitim, bireylerin tutum, inanç ve değerleriyle biçimlenen cinsiyet ve cinsellik ile ilgili gerekli bilgileri edindikleri bir süreçtir ve cinselliğin eğitim boyutu, ahlaki ve sosyal boyutu kadar önemlidir (Martin, Riazi, Firoozi ve Nasiri, 2020). Diğer bir tanımla cinsel eğitim; bilgilendirme, tutum geliştirme, değerler, kişiler arası iletişim ve mahremiyet konularını kapsayan bir eğitimdir (Çalışandemir ve diğerleri, 2008; Güneş, 2018). Martin ve diğerleri (2020) ise, cinsel eğitimin altı alanda bilgi ve tutumdan oluştuğunu belirtmektedir. Bunlar cinsel eğitimin ilkeleri, cinsel kimlik, cinsel gelişim aşamaları ve uygun cinsel eğitim yaklaşımları, çocukların cinsellikle ilgili soruları, çocuklarda mastürbasyon ve cinsel istismar olarak gruplanmıştır. Kardeş ve Güney Karaman (2018) ise, çocuğa verilecek cinsel eğitimin içeriğinin çocuğun gelişim düzeyine uygun olması, ihmal ve istismara yönelik bilgileri içermesi ve çocuğun ailesi ve diğer bileşenleri kapsaması gerektiğini belirlemiştir. Bu alanda çalışan araştırmacıların vurguladığı üzere cinsel eğitimden bahsedildiğinde cinsellikten çok daha geniş bir kavramdan bahsedilmektedir.

Erken çocuklukta cinsel eğitim ele alındığında ise bazı hususlar ön plana çıkmaktadır. Bunlar; cinsel eğitimin kapsamı, cinsel eğitim verilmeye kaç yaşında başlanabileceği, cinsel eğitimin kim tarafından ve nasıl verilmesi gerektiğidir. Erken çocuklukta cinsel eğitimin amacı fiziksel, zihinsel ve duygusal olgunluk süreçlerinin yeterli bir şekilde anlaşılmasını sağlamak, cinsel uyum ve gelişimle ilgili korku ve kaygıyı azaltmak olarak tanımlanmıştır (Chairilsyah, 2019). Güzelyurt (2020), okul öncesi dönemde cinsel eğitimi; çocukların cinsel içerikli soruları, bedenini tanıması, farklı cinsiyetteki bedenleri merakı ve cinsel istismardan korunmak için bilmeleri ve öğrenmeleri gereken davranışlar olarak gruplandırmaktadır.

Cinsellik bir bebek doğduğu an onun kız mı yoksa erkek mi olduğuyla yani cinsiyet kavramıla başlamaktadır. Cinsiyet ise bireyi kadın ya da erkek olarak tanımlayan biyolojik özelliklerin tümüdür (World Health Organization, 2000). Cinsellik kadın ve erkek olmanın tüm yönlerini ifade eden, biyolojik, psikolojik, davranışsal, kültürel, sosyal, ahlaki, dini ve eğitimsel boyutları olan insan kişiliğinin en önemli yönüdür (Kakavoulis, 1998). Bütüncül bir bakış açısıyla cinsellik, bireylerin çevreleriyle etkileşimleri arasında ortaya çıkan ve gelişen karmaşık bir gelişim alanı olarak tanımlanmaktadır (Balter, van Rhijn ve Davies, 2016).

Cinsellik kavramı çocukların henüz üreme fonksiyonu kazanmamaları nedeniyle çocukluktan ayrı tutulmakta, ergenliğe atfedilmektedir (Kurtuncu, Utaş Akhan, Tanır ve Yıldız, 2015). Oysa cinsellik ergenlikte birdenbire ortaya çıkmamaktadır. Erken çocukluğun 3-6 yaş arası dönemi, cinsel gelişimin oluşmasında en önemli yıllardır. Yapılan araştırmalar cinsel eğitimin, yaşamın erken dönemlerinden itibaren verilmeye başlaması gerektiğini vurgulamaktadır (Robinson ve Davies, 2016; Chairilsyah, 2019). Çocuklar sağlık ve esenlik içeren bir yaşam için erken yaşlardan itibaren etik ve saygın ilişkiler kurma ve cinsel okuryazarlık becerilerini geliştirme gereksinimi duymaktadırlar (Robinson ve Davies, 2016). Karmaşık bir değişim süreci olması ve edinilen bilgilerin kalıcı olması amacıyla cinsel eğitim, çocukluğun farklı dönemlerinde farklı şekilde ele alınmalıdır. Cinsel eğitim "0-5 yaş arası", "5-10 yaş arası" ve "ergenlik dönemi öncesi” şeklinde yaş gruplarına göre ve aşamalı olarak verilmelidir (Balter ve diğerleri, 2016; Chairilsyah, 2019). Çocuklara verilen cinsel eğitimin altı aylık aralarla tekrarlanması vurgulanmıştır (Katz ve Hamama, 2013; Kairys, Alexander, Block, Everett, Hymel, Johnson ve Bays, 1999).

Aile ve eğitim ortamlarında cinselliği telaffuz etmek tabu olarak görülmektedir. Oysa çocuklar erken çocukluk döneminde oldukça meraklıdır, cinsel içerikli konulara ilgisi fazladır, bu nedenle cinsel gelişim sürecine sorular sorarak başlar. Okul öncesi dönemde çocukların cinselliğe yönelik sorular sormaları gelişimsel bir özelliktir (Eliküçük ve Sönmez, 2011; Halstead ve Waite, 2001). Çocuklar en çok 'kadınlar neden hamile kalabilir?' 'Bebekler nereden geliyor?' 'Resimli kitaplarda kızlar yüzerken neden tişört giyiyorlar ama erkekler giymiyor? gibi sorular sormaktadırlar (Balter ve diğerleri, 2016). Dereobalı, Karadağ ve Sönmez'e 
göre (2013) çocukların sordukları soruların doğru olarak yanıtlanması çocukların bedenlerini tanıması ve koruması için önemli görülmektedir.

Cinsel eğitim hakkında bilgi edinme kaynakları aileler, öğretmenler ve çocuğun etrafındaki her türlü uyarandır. Etkili ve doğru bir cinsel eğitim ebeveynlerin açıklamalarıyla başlamalı, okul öncesi öğretmenleri tarafından anaokullarında desteklenmelidir. Aileler, cinsel eğitim için birincil kaynaktır. Ailelerin cinsel eğitim konusunda yeterli ve doğru bilgiye sahip olmadıkları bilinmektedir (Eliküçük ve Sönmez, 2011; Tuğut ve Gölbaşı, 2019; Petty, 2001). Aileler cinsel eğitim konusunda konuşmaktan kaçınmakta, konuştukları zaman da doğal davranmadıkları için cinsellik hakkında konuşmanın ayıp ya da günah olduğu düşüncesini çocukların bilincine yerleştirmektedir. Çocukların cinsel içerikli sorularını cevaplamamak, konuşmaların üstünü kapatmak çocukların bitmek bilmeyen merak duygularının yanlış yöne çevrilmesine ve çocukların yanlış bilgiler edinmesine neden olmaktadır (İşler, 2017). Yirmi birinci yüzyılın yaşam tarzındaki değişiklikler göz önünde bulundurulduğunda çocuğun aile dışındaki diğer sosyal ortamları, özellikle de okulların rolü önem kazanmıştır (Martin ve diğerleri, 2020). Cinsel eğitim gibi önemli normların aktarılmasında erken çocukluk eğitimcileri cinsel eğitimde en önemli ikinci kaynaktır. COVID-19 pandemisi nedeniyle uygulanan karantina tedbirleri öncesinde çocukların okulda öğretmenleriyle uzun vakit geçirmeleri; öğretmenleri, çocukların cinsel eğitimini destekleme konusunda uygun bir konuma yerleştirmektedir. Erken çocukluk eğitim kurumlarında cinsel eğitim programının uygulanması, çocukların cinsel eğitime dair bilgi ve tutumlarını geliştirmektedir (Martin ve diğerleri, 2020). Çocuklarının cinselliğe yönelen doğal merakları dış uyaranlardan önce ebeveynler ve öğretmenler tarafından doğru ve net bilgilerle karşılanmalıdır (Eliküçük ve Sönmez, 2011). Ailelerin ve öğretmenlerin cinsel eğitim konusundaki eksiklikleri, cinsel eğitim hakkında doğru bilinen yanlışların olması, çocukların sorduğu soruların konuşulmaması gereken konular olarak düşünülmesi ya da yanlış cevaplarla yanıtlanması çocuklarda cinsel gelişimin aksamasına yol açmaktadır (Deniz ve Gözütok, 2017). Cinsel eğitim sürecinde doğru kişiler aracılığıyla, yaş gruplarına göre uyarlanmış, planlı eğitim programlarına ve eğitim materyallerine ihtiyaç vardır. Bu materyallerden özellikle resimli çocuk kitapları güçlü bir kaynaktır.

Cinsel eğitime yönelik bilgi ihtiyacının yayınlar yoluyla karşılanması tarihsel olarak oldukça geç bir tarihte gerçekleşmiştir (Yılmaz, 2011). Resimli çocuk kitaplarının çocukların yaş, gelişim özellikleri, ilgi ve ihtiyaçları dikkate alınarak hazırlanması, çocukların kitaplara elleriyle somut olarak dokunabilmesi ve kitapları bağımsız inceleyebilmesi bu tür kitapların değerli eğitsel bir kaynak olduğunu düşündürmektedir. Kitaplar görsellerle içerikleri somutlaştırmakta ve çocukların kitap karakterleriyle özdeşim kurmasını sağlamaktadır (Güzelyurt, 2020). Yazarlar ve uzmanlar tarafından oluşturulan kitaplar çocuk yayını editörlerinin onayından geçmektedir. Kitaplar çocukların yaş ve anlama düzeyine uygun yazıldığı için kullanılan dil, çeşitli sosyo kültürel seviyedeki aile için anlaşılır hale gelmektedir. Çocuk kitaplarına ulaşmak satın alma, halk ve okul kütüphanelerinden ödünç alma, ikinci el kitap edinme ya da yakın çevreden değiş tokuş yapma gibi stratejilerle kolaylaşabilir. Kitaplar cinsel eğitimle ilgili yeterli bilgi ve beceriye sahip olmayan aile ve öğretmenleri destek sağlayabilir. Bu avantajlar çocuk kitaplarının cinsel eğitim sürecinde etkili bir şekilde kullanılabileceğini göstermekte (Sargın ve Tor, 2004) ve çocukların doğru ve yeterli bilgiye ulaşmaları için çocuk kitaplarının gücünden faydalanılması gereğine dikkat çekmektedir (Kır, 2013). Türkiye'de çocukların cinsel eğitimi konusunda ailelere, öğretmenlere ve toplumun diğer kesimlerine yönelik bilinçlendirme çabalarının yetersiz kaldığı bilinmektedir. Resimli çocuk kitapları yetersiz kalan toplumu bilinçlendirme problemine bir çözüm olarak düşünülebilir. Bu bağlamda erken çocukluk dönemine yönelik olarak hazırlanmış resimli çocuk kitaplarının cinsel eğitim unsurları açısından incelenmesi amaçlanmaktadır.

\section{Yöntem}

Araştırmanın bu bölümünde araştırma modeli, çalışma grubu, verilerin toplanması ve analizi, güvenirlik ve araştırmanın sınırlılıklarına ilişkin bilgilere yer verilmiştir.

\section{Araştırmanın Modeli}


Araştırma, nitel araştırma yöntemlerinden durum çalışması ile desenlenmiştir. Durum çalışması bir bireyi, grubu ya da kültür durumunu anlama, tanımlama, tahmin etme ya da kontrol etmeyi vurgulayan bir yaklaşımdır (Bassey, 1999).

\section{Araştırmanın Çalışma Grubu}

Araştırmanın çalışma grubunu, Türkçe ilk baskısı 2009-2020 yılları arasında olan, cinsel eğitim unsurlarını içeren, erken çocukluk dönemine yönelik resimli çocuk kitapları türünde 30 çeviri ve telif eser oluşturmaktadır. Türkiye'de erken çocukluk dönemine yönelik cinsel eğitim unsurlarını içeren ve araştırmacılar tarafından ulaşılabilen ilk kitap 2009 yılında yayınlandığı için, 2009 yılından itibaren yayınlanan resimli çocuk kitapları araştırma kapsamına alınmıştır. Araştırma kapsamında, derinlemesine araştırma yapabilmek için amaçlı örnekleme yöntemi kullanılmıştır. Amaçlı örnekleme, araştırmanın amacı doğrultusunda zengin verilere ulaşılmasını sağlar (Flick, 2014). Araştırma kapsamında incelenen resimli çocuk kitaplarının künye bilgileri araştırmanın ekinde sunulmuştur.

\section{Verilerin Toplanması ve Analizi}

Araştırmada kapsamında elde edilen verilere doküman incelemesi formu ile ulaşılmış, elde edilen veriler betimsel ile çözümlenmiştir. Veriler hem frekans ve yüzde değerleri içeren tablolarla sunulmuştur hem de betimsel bir yaklaşımla doğrudan alıntılar şeklinde ifade edilmiştir.

Doküman incelemesi, araştırılması hedeflenen olgular hakkında bilgi içeren yazılı belgelerin bulunmasını, kategorize etmek, araştırmak ve yorumlamak için kullanılan bir veri toplama tekniğidir (Payne ve Payne, 2004). Betimsel analizde elde edilen veriler, daha önceden belirlenen kavramsal çerçeve veya temalara göre özetlenir ve yorumlanır. Elde edilen verilerin çarpıcı bir şekilde yansıtılması amacıyla doğrudan alıntılara sık sık yer verilir. Betimsel analizde amaç, elde edilen bulguların düzenlenmiş ve yorumlanmış bir biçimde okuyucuya sunulmasıdır (Sözbilir, 2009).

Doküman incelemesi formunda cinsel eğitim unsurlarını barındıran kategoriler ve alt kategoriler oluşturulmuştur. Bunlar belirlenirken cinsel eğitim tanımları göz önünde bulundurulmuş ve cinsel eğitimin göstergesi olan genel temalar belirlenmiştir. Erken çocukluk döneminde verilmesi gereken cinsel eğitim unsurları ile ilgili literatür temel alınarak kategoriler ve alt kategoriler oluşturulmuştur. Özel bölgeler, güvenilecek kişiler, beden değeri, sırlar, dokunuşlar, yabancılar, erkek-kadın vücudu ve cinsel organ ismi olmak üzere 8 kategori ve bu kategorilere ait olan 34 alt kategori oluşturulmuştur. Oluşturulan kategoriler çocukların cinsel eğitime dair sorularını karşılar niteliktedir. Özel bölgeler kategorisi ile cinsel eğitim konusunu işleyen resimli çocuk kitaplarında çocukların özel bölgeleri olarak hangi bölgelere yer verildiği saptanmıştır. Güvenilecek kişiler kategorisi ile çocukların cinsel eğitiminde güvenilecekler listesine yer verilme durumu saptanmıştır. Beden değeri kategorisi ile çocukların bedenlerini tanımaları, sevmeleri bedenlerinin kendilerine ait olduğunu kavrama ve beden sevgisi kazanmalarının kitaplarda yer alma durumları saptanmıştır. Sırlar kategorisi ile çocuklara sırlar ve sürprizler arasındaki farkın kitaplarda yer alma durumu saptanmıştır. Dokunuşlar kategorisi ile istenmeyen dokunuşların, rahatsız eden dokunuşların ve bu dokunuşlar karşısında neler yapılması gerektiğinin yer alma durumu saptanmıştır. Yabancılar kategorisi ile çocukların kaybolduklarında neler yapmaları gerektiğinin ve yabancıların istenmeyen davranışları konusunda neler yapmaları gerektiğinin yer alma durumu saptanmıştır. Erkek kadın vücudu alt kategorisinde resimli çocuk kitaplarında kadın ve erkek vücutlarının çıplak resimlerine yer verme durumu, erkek ve kadın vücutlarının farklılıklarına yer verme durumu, hamilelikte anne vücudunun nasıl olduğu, sperm ve yumurta hücrelerine yer verme durumu saptanmıştır. Cinsel organ ismi kategorisi ile resimli çocuk kitaplarında cinsel organların anatomik ismine yer verme durumu saptanmıştır.

\section{Güvenirlik}

Araştırma kapsamına alınan resimli çocuk kitapları iki araştırmacı tarafından ayrı ayrı incelenmiştir. Araştırmacılar ayrı ayrı doküman incelemesi formuyla kategorileri belirlemiş ve kategorilere uygun içerikleri birbirinden bağımsız bir şekilde kodlamıştır. Miles ve Huberman'ın (2015) önerdiği formül kullanılarak görüş birliği ve görüş ayrılığı olan kodlar tespit edilmiştir. Kodlayıcılar arası uyum yüzdesinin \%90 olduğu 
görülmüştür. Uyum yüzdesinin \%70'in üzerinde olması güvenilir kabul edilmektedir (Miles ve Huberman, 2015). Böylece kodlayıcılar arası uyumun iyi düzeyde olduğu belirlenmiş, veri analizinin güvenirliği sağlanmıştır.

\section{Araștırmanın Sınırlılıkları}

Araştırma kapsamında incelenen kitaplar cinsel eğitim konulu, araştırmacıların ulaşabildiği ve baskısı devam eden resimli çocuk kitaplarıyla sınırlı kalmıştır.

\section{Bulgular}

Araştırmada incelenen resimli çocuk kitaplarının içerdiği cinsel eğitim kategorilerine ilişkin bulgulara Tablo 1'de yer verilmektedir.

Tablo 1. Incelenen kitaplarda cinsel eğitim kategorilerine ilişkin bulgular

\begin{tabular}{lccc}
\hline \multicolumn{1}{c}{ Kategoriler } & Kitap Sayısı & $\mathrm{f}$ & $\%$ \\
\hline Erkek-kadın vücudu & 9 & 140 & 42,1 \\
\hline Sirlar & 3 & 53 & 15,9 \\
\hline Özel bölgeler & 9 & 38 & 11,4 \\
\hline Yabancllar & 13 & 26 & 7,8 \\
\hline Cinsel organ ismi & 4 & 24 & 7,2 \\
\hline Dokunuşlar & 8 & 18 & 5,4 \\
\hline Güvenilecek kişiler & 8 & 18 & 5,4 \\
\hline Beden değeri & 3 & 16 & 4,8 \\
\hline Toplam & 57 & 333 & 100 \\
\hline
\end{tabular}

Tablo 1'de görüldüğü gibi incelenen çocuk kitaplarının \%42,1'i erkek-kadın vücuduna, \%15,9'u sırlara, $\% 11,4^{\prime}$ ü özel bölgelere, $\% 7,8^{\prime}$ i yabanclara, $\% 7,2^{\prime}$ si cinsel organ ismine, $\% 5,4^{\prime}$ ü dokunuşlara ve güvenilecek kişilere, \%4,8'i beden değerine yer verdiği bulunmuştur.

\section{Erkek-Kadın Vücudu}

Tablo 2. Erkek-kadın vücudu bilgisi içermesine ilişkin bulgular

\begin{tabular}{llcc}
\hline & & f & \% \\
\hline & Teo'nun 'Ben Nereden Geldim?' Kitabı & 29 & 20,71 \\
\cline { 2 - 4 } & Cinsel Eğitim Öyküleri & 25 & 17,9 \\
\cline { 2 - 4 } & Ben Nasıl Ben Oldum? & 53 & 37,85 \\
\cline { 2 - 4 } Erkek-Kadın & Ben Nereden Geldim? & 5 & 3,57 \\
\cline { 2 - 4 } Vücudu & Veli Nereye Gitti... & 13 & 9,28 \\
\cline { 2 - 4 } & Annemin Karnında & 3 & 2,14 \\
\cline { 2 - 4 } & Bebekler Nereden Gelir? & 6 & 4,28 \\
\cline { 2 - 4 } & Abla Oluyorum & 2 & 2,85 \\
\cline { 2 - 4 } & Nasıl Dünyaya Geldik? & 2 & 1,42 \\
\cline { 2 - 4 } & Toplam & 140 & 100 \\
\hline
\end{tabular}

Tablo 2'de görüldüğü gibi incelenen resimli çocuk kitaplarından 9'unda erkek-kadın vücutlarına yer verilmiş, 21'inde yer verilmemiştir. Erkek-kadın vücuduna en fazla yer veren kitabın \%37,85 ile "Ben Nasıl Ben Oldum?" isimli resimli çocuk kitabı olduğu görülmektedir. Bunu sırasıyla \%20,71 ile "Teo'nun 'Ben Nereden Geldim?' Kitabı", \%17,9 ile "Cinsel Eğitim Öyküleri", \%9,28 ile "Veli Nereye Gitti...", \%4,28 ile "Bebekler Nereden Gelir?", \%3,57 ile "Ben Nereden Geldim?", \%2,85 ile "Abla Oluyorum", \%2,14 ile "Annemin Karnında" isimli resimli çocuk kitaplarının takip ettiği görülmektedir. Erkek-kadın vücuduna en az yer veren kitabın \%1,42 ile "Nasıl Dünyaya Geldik?" isimli resimli çocuk kitabı olduğu görülmektedir. Resimli çocuk kitaplarında en fazla tekrar eden erkek-kadın vücudu 'Ben Nasıl Ben Oldum' isimli resimli çocuk kitabında "Annenin karnında döllenmek için bekleyen bir yumurta vardır.", "Annenin karnında bebek için özel bir oda vardır." ve "Bebek annenin karnında çok uzun süre oyalanır." cümleleri ile belirtilmiştir. 'Teo'nun “Ben Nereden Geldim?” Kitabı' isimli resimli çocuk kitabında "Kadın ve erkek vücutları birbirinden farklı parçalara sahiptir. Mesela kızlar büyüyünce yavaş yavaş memeleri büyür ama erkeklerinki büyümez. Kadınların sakalı çıkmaz, erkeklerin çıkar. Kadınların vulvası vardır, erkeklerin penisi vardır. Kız ve 
erkeklerin çiş yaptıkları organlar da farklıdır. Kadınların vulvasında ve erkeklerin penisinin ucunda çiş yapmak için ufak bir delik vardır, oradan çiş yaparız. Erkekler büyüdükçe penisleri de büyür." cümleleri ile belirtilmiştir. 'Cinsel Eğitim Öyküleri' isimli resimli çocuk kitabında "Bebek, anne karnı içindeki özel bir yuvada oluşur.", "Anne karnı, etrafı yumuşacık duvarlarla kaplı çok rahat bir yerdir." ve "Bebeğin anne karnında bu yolculuğu yaklaşık dokuz ay sürer." cümleleri ile belirtilmiştir.

\section{Sirlar}

Tablo 3. Sırlar bilgisi içermesine ilişkin bulgular

\begin{tabular}{llcc}
\hline & & f & \% \\
\hline \multirow{4}{*}{ Sırlar } & Bu Vücut Benim! Ben Ne Dersem O Olur! & 17 & 32 \\
\cline { 2 - 4 } & Sir Versem Saklar Misın? & 35 & 66 \\
\cline { 2 - 4 } & Sana Bir Daha Sır Vermeyeceğim & 1 & 2 \\
\cline { 2 - 4 } & Toplam & 53 & 100 \\
\hline
\end{tabular}

Tablo 3'te görüldüğü gibi incelenen resimli çocuk kitaplarından 3'ünde sırlara yer verilmiş, 27'sinde yer verilmemiştir. Sırlara en fazla yer veren kitabın \%66 ile "Sır Versem Saklar Mısın?" isimli resimli çocuk kitabı olduğu görülmektedir. Bunu \%32 ile “Bu Vücut Benim! Ben Ne Dersem O Olur!”, \%2 ile "Sana Bir Daha Sır Vermeyeceğim" isimli resimli çocuk kitaplarının takip ettiği görülmektedir. Sırlar 'Sır Versem Saklar Mısın?' isimli resimli çocuk kitabında "Saklaması eğlenceli olan sürprizler kişileri mutlu eder. Biri sana rahatsız edici şekilde dokunursa ve senin kötü hissetmene neden olursa bu kötü sırdır ve saklanmamalıdır." cümlesi ile belirtilmiştir. ‘Bu Vücut Benim! Ben Ne Dersem O Olur!' isimli resimli çocuk kitabında "Sürprizler ve sırlar farklıdır. Sürprizler keyifli ve eğlenceli şeylerdir ve mutlaka başkalarına da söylenir. Sırlar is kendinizi kötü hissetmenize sebep olabilirler, hele de sir veren kişi size bunu kimseye söylememenizi tembihlediyse. O yüzden bizim ailemizde sır tutulmaz." ve "Biri senden sır saklamanı isterse ona şöyle de: Ben sır saklamam." cümleleri ile belirtilmiştir.

\section{Özel Bölgeler}

Tablo 4. Özel bölgeler bilgisi içermesine ilişkin bulgular

\begin{tabular}{llcc}
\hline & & $\mathbf{f}$ & $\mathbf{\%}$ \\
\hline & Teo'nun 'Ben Nereden Geldim?' Kitab1 & 9 & 23,7 \\
\cline { 2 - 4 } & Cinsel Eğitim Öyküleri & 6 & 15,8 \\
\cline { 2 - 4 } & Ben Nasil Ben Oldum? & 2 & 5,26 \\
\cline { 2 - 4 } Özel Bölgeler & Abla Oluyorum & 1 & 2,63 \\
\cline { 2 - 4 } & Bu Vücut Benim! Ben Ne Dersem O Olur! & 10 & 26,31 \\
\cline { 2 - 4 } & Bu Beden Benim & 1 & 2,63 \\
\cline { 2 - 4 } & Kendimi Koruyorum & 1 & 10,53 \\
\cline { 2 - 4 } & Hüso ve Mahremiyet Eğitimi & 4 & 10,52 \\
\cline { 2 - 4 } & Kendimizi Taniyoruz. Hayır! Demeyi Öğreniyoruz. & 4 & 100 \\
\cline { 2 - 4 } & Toplam & 38 & \\
\hline
\end{tabular}

Tablo 4'te görüldüğü gibi incelenen resimli çocuk kitaplarından 9'unda özel bölgelere yer verilmiş, 21'inde yer verilmemiştir. Özel bölgelere en fazla yer veren kitabın \%26,31 ile "Bu Vücut Benim! Ben Ne Dersem O Olur!” isimli resimli çocuk kitabı olduğu görülmektedir. Bunu \%23,7 ile “Teo'nun ‘Ben Nereden Geldim?' Kitabı", \%15,8 ile "Cinsel Eğitim Öyküleri", \%10,52 ile "Hüso ve Mahremiyet Eğitimi" ve "Kendimizi Tanıyoruz. Hayır! Demeyi Öğreniyoruz.", \%5,26 ile "Ben Nasıl Ben Oldum?" isimli resimli çocuk kitaplarının takip ettiği görülmektedir. Özel bölgelere en az yer veren kitapların \%2,63 ile "Abla Oluyorum”, "Bu Beden Benim" ve "Kendimi Koruyorum" isimli resimli çocuk kitaplarının olduğu görülmektedir. Özel bölgeler ‘Bu Vücut Benim! Ben Ne Dersem O Olur!' isimli resimli çocuk kitabında "Erkeklerin penisi, testisleri ve poposu vardır. Kızların vajinası, memeleri ve poposu vardır. Kızların yaşı büyüdükçe memeleri büyüyüp gelişir." cümleleri ile belirtilmiştir. 'Ben Nasıl Ben Oldum?' isimli resimli çocuk kitabında "Ben henüz yokken babamın testislerinde bir tohum, annemin karnında da minicik bir yumurtaydım." cümlesi ile belirtilmiştir. 'Kendimi Koruyorum' isimli resimli çocuk kitabında "Vücudunda mayonun örttüğü yerleri, özellikle tanımadığın kişiler kesinlikle ellememeli." cümlesi ile belirtilmiştir. 


\section{Yabancilar}

Tablo 5. Yabancular bilgisi içermesine ilişkin bulgular

\begin{tabular}{|c|c|c|c|}
\hline & & $\mathbf{f}$ & $\%$ \\
\hline \multirow{14}{*}{ Yabancilar } & Bu Vücut Benim! Ben Ne Dersem O Olur! & 1 & 3,85 \\
\hline & Elif Asla Yabancilarla Gitmez & 1 & 3,85 \\
\hline & Bu Beden Benim & 1 & 3,85 \\
\hline & Kendimi Koruyorum & 1 & 3,85 \\
\hline & Ben Kaybolmam Ki & 3 & 11,53 \\
\hline & Ben Herkesle Gitmem Ki & 2 & 7,7 \\
\hline & Ben Kaybolmam Ki & 3 & 11,53 \\
\hline & Nele Diyor ki: Yabancılarla Hiçbir Yere Gitmem & 2 & 7,7 \\
\hline & Yabancilar. Kaybolursan Ne Yaparsin? & 3 & 11,53 \\
\hline & Ben Kaybolmam & 3 & 11,53 \\
\hline & İnci Yabancilarla Gitmez & 2 & 7,7 \\
\hline & Kendimizi Tanıyoruz. Hayır! Demeyi Öğreniyoruz. & 3 & 11,53 \\
\hline & Çağlar Tanımadığ İnsanlarla Bir Yere Gitmez & 1 & 3,85 \\
\hline & Toplam & 26 & 100 \\
\hline
\end{tabular}

Tablo 5'te görüldüğü gibi incelenen resimli çocuk kitaplarından $13^{\prime}$ ünde yabancllara yer verilmiş, $17^{\prime}$ sinde yer verilmemiştir. Yabancılara en fazla yer veren kitapların \%11,53 ile "Ben Kaybolmam Ki", "Ben Kaybolmam Ki", "Yabancilar. Kaybolursan Ne Yaparsın?", "Ben Kaybolmam" ve "Kendimizi Taniyoruz. Hayır! Demeyi Öğreniyoruz." isimli resimli çocuk kitapları olduğu görülmektedir. Bunu \%7,7 ile "Ben Herkesle Gitmem Ki!”, “Nele Diyor Ki: Yabancılarla Hiçbir Yere Gitmem” ve “İnci Yabancılarla Gitmez” isimli resimli çocuk kitaplarının takip ettiği görülmektedir. Yabancılara en az yer veren kitapların \%3,85 ile "Bu Vücut Benim! Ben Ne Dersem O Olur!", “Elif Asla Yabancilarla Gitmez", “Bu Beden Benim”, “Kendimi Koruyorum" ve "Çağlar Tanımadığı İnsanlarla Bir Yere Gitmez" isimli resimli çocuk kitapları olduğu görülmektedir. Yabanclar 'Kendimizi Tanıyoruz Hayır Demeyi Öğreniyoruz' isimli resimli çocuk kitabında “Tanımadığımız insanlar bize bir yiyecek ikram ettiklerinde, yanımızda aile büyügüumüz ya da öğretmenimiz gibi bizi koruyacak yetişkinler yoksa yiyeceği almamalıyız. Ayrıca bizi bir yere götürmek istediklerinde de 'HAYIR!' demeli, diretirlerse de bağırarak yardım istemeliyiz." cümleleri ile belirtilmiştir. 'Ben Herkesle Gitmem Ki' isimli resimli çocuk kitabında "Lu, güven listesindeki isimlerden başka hiç kimseyle hiçbir yere gidemez!" cümlesi ile belirtilmiştir. 'Ben Kaybolmam Ki' isimli resimli çocuk kitabında "Kaybolan için birimci kural ayakta durmak ve seslenmek. İkinci kural eğer hemen bulunamazsan annene, babana telefon etmek. Üçüncü kural eğer telefon numarası hatırlamıyorsan polise telefon et. Dördüncü kural asla yabancıyla bir yere gitme. Beşinci kural yardıma ihtiyacın olduğunda çok insanın olduğu ve iyi görülebileceğin başka bir yere git. Altıncı kural paniğe kapılmak yok." cümleleri ile belirtilmiştir.

\section{Cinsel Organ İsmi}

Tablo 6. Cinsel organ ismi içermesine ilişkin bulgular

\begin{tabular}{llcc}
\hline & & $\mathbf{f}$ & $\mathbf{\%}$ \\
\hline & Teo'nun 'Ben Nereden Geldim?' Kitabı & 7 & 29,1 \\
\cline { 2 - 4 } Cinsel Organ İsmi & Cinsel Eğitim Öyküleri & 10 & 41,7 \\
\cline { 2 - 4 } & Ben Nasıl Ben Oldum? & 4 & 16,7 \\
\cline { 2 - 4 } & Bu Vücut Benim! Ben Ne Dersem O Olur! & 3 & 12,5 \\
\cline { 2 - 4 } & Toplam & 24 & 100 \\
\hline
\end{tabular}

Tablo 6'da görüldüğü gibi incelenen resimli çocuk kitaplarından 4'ünde cinsel organların adlarına yer verilmiş, 26'sında yer verilmemiştir. Cinsel organların adlarına en fazla yer veren kitabın \%41,7 ile "Cinsel Eğitim Öyküleri" isimli resimli çocuk kitabı olduğu görülmektedir. Bunu \%29,1 ile "Teo'nun ‘Ben Nereden Geldim?' Kitabı", \%16,7 ile "Ben Nasıl Ben Oldum?", \%12,5 ile “Bu Vücut Benim! Ben Ne Dersem O Olur!” isimli resimli çocuk kitaplarının takip ettiği görülmüştür. Cinsel organ adları 'Cinsel Eğitim Öyküleri' isimli resimli çocuk kitabında "Kadın cinsel organına vajina, erkek cinsel organına da penis denir ama arkadaşlarımızın bir kısmı bu isimleri bilmediği için onlara farklı isimler takmışlardır. Örneğin, vajinaya 'kuku', penise de 'pipi' diyebilirler." cümleleri ile anatomik olarak belirtilmiştir. 'Bu Vücut Benim! Ben Ne Dersem O Olur!' isimli resimli çocuk kitabında "Kızların vajinası, memeleri ve poposu vardır. Kızların yaşı 
büyüdükçe memeleri büyüyüp gelişir. Bunlar özel bölgelerimizin doğru isimleridir." cümleleri ile anatomik olarak belirtilmiştir. 'Teo'nun "Ben Nereden Geldim?" Kitabı' isimli resimli çocuk kitabında "Kadınların vulvası vardır, erkeklerin penisi vardır." cümlesi ile anatomik olarak belirtilmiştir. Ancak "Ben Nasıl Ben Oldum?" isimli resimli çocuk kitabında ise "Babanın pipisi, annenin kukusu vardır." cümlesi ile cinsel organ adlarının anatomik adlarıyla değil takma adlarıyla belirtildiği görülmektedir. İncelenen 30 kitaptan sadece 4'ünde cinsel organ adına rastlanmış bunların da 2'sinde cinsel organların anatomik adlarına yer verilmiş, birinde takma adlarına yer verilmiş, birinde de hem anatomik hem de takma adlar birlikte kullanılmıştır. 26 kitapta cinsel organ isimlerine hiç yer verilmediği görülmektedir.

\section{Dokunuşlar}

Tablo 7. Dokunuşlar bilgisi içermesine ilişkin bulgular

\begin{tabular}{lllc}
\hline & & $\mathbf{f}$ & \multicolumn{1}{c}{$\%$} \\
\hline & Cinsel Eğitim Öyküleri & 1 & 5,55 \\
\cline { 2 - 4 } & Bu Vücut Benim! Ben Ne Dersem O Olur! & 5 & 27,77 \\
\cline { 2 - 4 } Dokunuşlar & Sir Versem Saklar Misın? & 1 & 5,55 \\
\cline { 2 - 4 } & Kirmızı Çizgi & 2 & 11,13 \\
\cline { 2 - 4 } & Bedenim Bana Ait & 5 & 27,77 \\
\cline { 2 - 4 } & Bu Beden Benim & 1 & 5,55 \\
\cline { 2 - 4 } & Kendimi Koruyorum & 1 & 5,55 \\
\cline { 2 - 4 } & Yetişkinler Beni İncitiyor & 2 & 11,13 \\
\cline { 2 - 4 } & Toplam & 18 & 100 \\
\hline
\end{tabular}

Tablo 7'de görüldüğü gibi incelenen resimli çocuk kitaplarından 8'inde dokunuşlara yer verilmiş, 22'sinde yer verilmemiştir. Dokunuşlara en fazla yer veren kitapların \%27,77 ile "Bu Vücut Benim! Ben Ne Dersem O Olur!" ve "Bedenim Bana Ait" isimli resimli çocuk kitapları olduğu görülmektedir. Bunu \%11,13 ile "Kırmızı Çizgi" ve "Yetişkinler Beni İncitiyor" isimli resimli çocuk kitaplarının takip ettiği görülmektedir. Dokunuşlara en az yer veren kitapların \%5,55 ile "Cinsel Eğitim Öyküleri”, “Sır Versem Saklar Mısın?”, "Bu Beden Benim” ve "Kendimi Koruyorum" isimli resimli çocuk kitapları olduğu görülmektedir. Dokunuşlar konusunda bilgiler 'Bedenim Bana Ait' isimli resimli çocuk kitabında "Birine dokunmam gerekiyorsa ama ben bunu istemiyorsam, o zaman bunu yapmıyorum ve şöyle diyorum: "Hayır, sana dokunmak hoşuma gitmiyor! Bunu istemiyorum!" cümlesi ile belirtilmiştir. "Kırmızı Çizgi" isimli resimli çocuk kitabında "Biri seni rahatsız ederse, sana dokunmaya kalkarsa o zaman bir aslan gibi ‘Hrrrrr' diye kükre!"cümlesi ile belirtilmiştir. "Bu Vücut Benim! Ben Ne Dersem O Olur!" isimli resimli çocuk kitabında "Babamın yanında yüzüp elimi tutması beni güvende hissettirir." ve "Okuldaki büyük çocuklardan biri yanıma çok fazla yaklaştığında kendimi güvende hissetmem. Rahatsız olurum ve kendimi tehlikede hissederim." cümleleri ile belirtilmiştir.

\section{Güvenilecek Kişiler}

Tablo 8. Güvenilecek kişiler bilgisi içermesine ilişkin bulgular

\begin{tabular}{llll}
\hline & & F & \% \\
\hline & Bu Vücut Benim! Ben Ne Dersem O Olur! & 1 & 5,6 \\
\cline { 2 - 4 } & Sır Versem Saklar Mısın? & 5 & 27,8 \\
\cline { 2 - 4 } Güvenilecek Kişiler & Kırmızı Çizgi & 1 & 5,6 \\
\cline { 2 - 4 } & Bedenim Bana Ait & 1 & 5,6 \\
\cline { 2 - 4 } & Kendimi Korurum & 2 & 11 \\
\cline { 2 - 4 } & Ben Herkesle Gitmem Ki & 2 & 11 \\
\cline { 2 - 4 } & Hüso ve Mahremiyet Eğitimi & 1 & 5,6 \\
\cline { 2 - 4 } & Yetişkinler Beni İncitiyor & 5 & 27,8 \\
\cline { 2 - 4 } & Toplam & 18 & 100 \\
\hline
\end{tabular}

Tablo 8'de görüldüğü gibi incelenen resimli çocuk kitaplarından 8'inde güvenilecek kişilere yer verilmiş, 22 'sinde yer verilmemiştir. Güvenilecek kişilere en fazla yer veren kitapların \%27,8 ile "Sır Versem Saklar Mısın?" ve "Yetişkinler Beni İncitiyor" isimli resimli çocuk kitapları olduğu görülmektedir. Bunu \%11 ile "Kendimi Korurum" ve "Ben Herkesle Gitmem Ki" isimli resimli çocuk kitaplarının takip ettiği görülmektedir. Güvenilecek kişilere en az yer veren kitapların \%5,6 ile "Bu Vücut Benim! Ben Ne Dersem O Olur!", "Kırmızı Çizgi", “Bedenim Bana Ait” ve "Hüso ve Mahremiyet Eğitimi” isimli resimli çocuk kitapları 
olduğu görülmektedir. Güvenilecek kişiler 'Sır Versem Saklar Mısın?' isimli resimli çocuk kitabında “İyi hissetmenin ve tekrar mutlu olmanın tek yolu, bu sırrı bir büyügüne anlatmaktır.", "Bu kötü bir sırdır ve kendini daha iyi hissetmek için bir büyüğünden yardım almalısın.", "Kötü bir sır olduğu için bunu bir büyügüne anlatmalısın.", "Bu kişi annen, baban, teyzen, amcan ya da sınıf öğretmenin gibi güvenebileceğin biri olmalıdır. Kötü bir sırrı onlarla paylaşmak çok doğru bir davranıştır." ve "Sakladığın kötü bir sır varsa en iyisi, gidip bunu bir büyüğüne söylemektir. Bir yetişkinler sırrını paylaşmak bazen zor gelebilir. Böyle zamanlarda cesur ol ve sırrı anlatarak doğru şeyi yaptığında kendini ne kadar iyi hissedeceğini düşün." cümleleri ile belirtilmiştir. 'Ben Herkesle Gitmem Ki' isimli resimli çocuk kitabında "Lu'nun Listesi" başlı̆̆ 1 altında güvenilecek kişilere yer verilmiştir. "Listeye göre Lu; annesine babasına sormadan annesi, babası, Fips, anneannesi, babaannesi, dedesi, Julia Teyzesi, Bayan Besenbinder ile gidebilir. Ann-Katrın ile ancak evin arkasındaki oyun alanına kadar gidebilir." cümleleri ile belirtilmiştir. 'Hüso ve Mahremiyet Eğitimi' isimli resimli çocuk kitabında "Güven tablosundaki kişiler, sen tuvaletteyken ve üzerini değiştirirken sana yardım edebilir. Bunun dışında güven tablosunda olmayan biri senin özel bölgelerine dokunursa sana yardımcı olmaları için bunu hemen tablondaki kişilere anlatmalısın. Tablondaki insanlar da sana sen izin vermeden dokunmamalı." cümleleri ile belirtilmiştir.

\section{Beden Değeri}

Tablo 9. Beden değeri bilgisi içermesine ilişkin bulgular

\begin{tabular}{lllc}
\hline & & F & \% \\
\hline & Bu Vücut Benim! Ben Ne Dersem O Olur! & 6 & 37,5 \\
\cline { 2 - 4 } Beden Değeri & Bedenim Bana Ait & 8 & 50 \\
\cline { 2 - 5 } & Bu Beden Benim & 2 & 12,5 \\
\cline { 2 - 5 } & Toplam & 16 & 100 \\
\hline
\end{tabular}

Tablo 9'da görüldüğü gibi incelenen resimli çocuk kitaplarından 3'ünde beden değerine yer verilmiş, 27 'sinde yer verilmemiştir. Beden değerine en fazla yer veren kitabın \%50 ile "Bedenim Bana Ait" isimli resimli çocuk kitabı olduğu görülmektedir. Bunu \%37,5 ile “Bu Vücut Benim! Ben Ne Dersem O Olur!” ve \%12,5 ile “Bu Beden Benim" isimli resimli çocuk kitaplarının takip ettiği görülmektedir.

Beden değeri ‘Bedenim Bana Ait' isimli resimli çocuk kitabında “Benim adım Clara ve ben çok özel bir şeye sahibim: bedenime! Bedenim sadece bana ait!” cümlesi ile belirtilmiştir. 'Bu Beden Benim!' isimli resimli çocuk kitabında "Bedenimizin her parçası çok değerli ve özel." cümlesi ile belirtilmiştir. 'Kendimi Korurum' isimli resimli çocuk kitabında "İnsan ya da hayvan hiç fark etmez. Her canlı kendisine kötü davranıldığında mutsuz olur ve kimseye güvenemez. Maskarayı sevdikçe o da bize güvenmeyi ve bizden korkmamayı öğrenmişti." cümleleri ile belirtilmiştir.

\section{Sonuç ve Tartışma}

Resimli çocuk kitapları, çocukların cinsel içerikli sorularını yanıtlayarak onların meraklarını gidermektedir. Çocuğun hem kendi bedenini hem de farklı cinsiyetteki bedenleri tanımasını sağlamaktadır. Çocuklara öğrenmeleri gereken kritik davranışları öğreterek çocukların cinsel istismardan korunmasını sağlayabilir. Gerekli bilgilerin çocuk kitapları yoluyla edinilmesi doğal cinsel gelişimden utanmanın baskısını azaltabilir. Çocukların cinsel gelişiminin sağlıklı bir şekilde desteklenmesi için yaşamın ilk yıllarından itibaren cinsel eğitim verilmeli, aileler ve okul öncesi öğretmenleri cinsel eğitimin kapsamı konusunda bilinçlenmelidir. Çocuk kitapları cinsel eğitim için doğru ve güvenilir bilgi kaynakları olan aileler ve öğretmenler tarafından kullanılabilecek değerli eğitsel bir kaynaktır.

İncelenen kitaplarda en çok erkek-kadın vücuduna, ardından sırayla sırlara, özel bölgelere, yabancılara, cinsel organ ismine, dokunuşlara ve güvenilecek kişilere yer verildiği bulunmuştur. Kitaplarda en az yer verilen cinsel eğitim unsuru beden değeridir. Cinsel eğitim, cinsellikten çok daha geniş bir kavramdır (World Health Organization, 2006; Martin ve diğerleri, 2020; Çalışandemir ve diğerleri, 2008; Güneş, 2018; Kardeş ve Güney Karaman, 2018). Cinsel eğitim cinsiyet kimlikleri, cinsel gelişim aşamaları, uygun cinsel eğitim yaklaşımları, çocukların cinsellikle ilgili soruları, çocuklarda mastürbasyon ve cinsel istismardan korunma olarak tanımlanabilir. Cinsel eğitimin geniş tanımında ele alınan konuların incelenen kitaplarda yer alması, 
resimli çocuk kitaplarının cinsel eğitim sürecinde hem ailelerin hem de öğretmenlerin işini kolaylaştıracak güçlü bir eğitsel materyal olduğunu düşündürmektedir. Işıtan (2016), yaptığı çalışmada özel amaçla yazılmış çocuk kitaplarına dikkat çekmiş, cinsel eğitim gibi özel amaçlarla yazılan resimli çocuk kitaplarının sayısının artması gerektiğini ve bu kitaplarının alan uzmanlarınca incelenmesi gerektiğini belirtmiştir. Güzelyurt (2020), cinsel eğitim ve cinsel istismardan korunma konularını içeren resimli çocuk kitaplarının aşamalı bir şekilde, çocukların yaşlarına uygun ve içinde bulunulan toplumun kültürel özellikleri dikkate alınarak yazılması gerektiğini vurgulamıştır. Deniz ve Gözütok (2017) ise, çalışmalarında incelemiş oldukları çocuk kitaplarının metin ve görsellerinde cinsel eğitimde kullanılabilecek doğru yaklaşımların mevcut olduğu saptamıştır. Cinsel eğitim unsurları içeren resimli çocuk kitapları, çocukların ilgisini çekerek cinsel eğitimin ailede ve okulda daha rahat verilmesini sağlayabilir. Lestari, Iswanti ve Haji, (2017), erken yaşta çocuklarda cinsel eğitimi tabu olarak gören toplumlarda bu anlayışın çocuklarda cinsel istismarın öncülerinden biri olduğunu belirterek cinsel eğitim sürecinde çocuklar için çekici bir materyal olan kukla kullanımına dikkat çekmiştir. Çocukların ilgisini çeken yöntemlerle ve materyallerle verilecek cinsel eğitimin daha etkili olacağı düşünülmektedir. Yapılan araştırmalar, ebeveynlerin çocuklarıyla cinsel eğitimle ilgili konularda konuşmak için yetersiz ve rahatsız olduklarını göstermektedir (Tuğut ve Gölbaşı, 2019; Tuğrul ve Artan, 2001). İstanbul'da sağlık çalışanlarıyla yapılan bir çalışmada kültürün cinsel eğitimle ilgili tutumlar üzerinde etkili olduğu, utanç ve utangaçlığın oldukça yaygın olduğu bulunmuştur (Kurtuncu ve diğerleri, 2015). Çocuklara uygun bilgiler vermek, uygun şekilde davranabilmek ve rehberlik edebilmek için öğretmenlerin kendilerinin de bilgi ve becerilerinin geliştirilmesine ihtiyaçları olduğu ve çocuklara cinsel eğitim vermeye hazır olmadıklarını vurgulamıştır (Balter ve diğerleri, 2016). Bir başka araştırmada Endonezyalı öğretmenler, çocukların cinsel eğitime gereksinim duyduklarını belirtmişlerdir (Astuti, Sugiyatno ve Aminah, 2017). İsveç'te 3-6 yaş çocuklarla çalışan öğretmenler, çocukların cinsel eğitim ihtiyaçlarına karşı diyalog kurmak yerine tepkisel yanıtlar vermekte ve nadiren çocuklarla cinsellik hakkında konuşmaktadırlar (Larrson ve Svedin, 2002). Yunanlı öğretmenlerin yarısı ve İskoç öğretmenlerin sadece \%14'ü anaokulunda günlük etkinlikler yoluyla cinsel eğitim vermek konusunda kendilerini rahat hissetmektedirler (Menmuir ve Kakavoulis, 1999). Cinsel eğitimle ilgili müfredat kaynaklı bir engel olmamasına rağmen okul öncesi eğitim ortamlarında cinsel eğitimin nadiren verildiği bilinmektedir. Türkiye'de yürürlükte olan Milli Eğitim Bakanlığı 0-36 Aylık Çocuklar İçin Eğitim Programında, cinsel gelişim ve eğitim ile ilgili açıklamalara yer verildiği ve çocukların gereksinimleri doğrultusunda öğretmenlerin cinsel eğitime yönelik etkinlikler yapabilecek esneklikte olduğu saptanmıştır (Deniz ve Yıldız Altan, 2019). Bu sonuçlar ebeveynlerden öğretmenlere ve hatta sağlık çalışanlarına kadar cinsel eğitim konusunda toplumun bilgi yetersizliği olduğunu ve utangaçlığını ortaya koymaktadır. Bu durumun çocukların cinsellik konusunda bilgilerinin sınırlı kalmasına yol açtığı düşünülmektedir. Oysa cinsel gelişim ve eğitim süreçlerinde çocuklar doğru ve yanlış bilgileri ebeveynleri ve öğretmenlerinin bilgileri ve tutumları sayesinde ayırt eder (Ünal, 2017). Cinsel eğitim unsurlarına yer veren resimli çocuk kitapları, kültürel normlar ve cinselliğin tabu olması nedeniyle yetersiz bilgilere sahip yetişkinler için güvenilir ve faydalı bir kaynak olabilir. Resimli çocuk kitapları, ebeveynlerin çocuklarıyla aile içinde, okul öncesi öğretmenlerinin öğrencileriyle sınıfta cinsel eğitim konusunda sohbetlerine zemin hazırlayabilir. Kitaplar bir yandan bilgi eksikliğini giderirken diğer yandan cinsellik konusunda konuşurken hissedilen rahatsızlıkların önüne geçebilir.

İncelenen kitaplarda en çok erkek-kadın vücuduna yer verildiği bulunmuştur. Yağan Güder ve Alabay, (2018), erkek ve kadın vücudu ve gebelik döneminin çocukların en çok merak ettikleri konular arasında yer aldığını bulmuştur. Erkek kadın vücudu konusuna yer veren kitaplar çocuklara bedenlerini tanıtmakta, erkekkadın vücutları arasındaki farklılıklara yer vermektedir. Çocukların cinsel eğitimin

de ilk adım çocuklara bedenlerini tanıtmaktır ve çocuklara öncelikle bedenlerini tanıtmak cinsel eğitimin aşamalı yapısını gösterir. Yapılan araştırmalar da cinsel eğitimin aşamalı şekilde gerçekleştirilmesi gerektiğini göstermektedir (Balter ve diğerleri, 2016; İşler, 2017; Kardeş ve Güney Karaman, 2018).

Beden değeri konusunun incelenen resimli çocuk kitaplarında en az yer verilen unsur olduğu sonucuna ulaşılmıştır. Beden değeri çocukların bedenlerini tanımaları ile paralel olarak gelişmesi gereken bir cinsel eğitim unsurudur. Güzelyurt'un (2020) yapmış olduğu çalışmada da benzer bulgulara ulaşıldığı 
görülmektedir. Beden değeri konusunun kitaplarda daha fazla yer alması tahmin edilebilir bir sıra ile cinsel eğitimin verilmesi için önemlidir. Yapılan araştırmalar cinsel eğitimin planlı, programlı ve aşamalı bir şekilde ilerlemesi gerektiğini ortaya koymaktadır (Konur, 2006; Çakşak, 2018; Güzelyurt, 2020; Kardeş ve Güney Karaman, 2018). Planlı, programlı bir cinsel eğitimin gerçekleşebilmesi için ön koşul çocukların bedenlerini tanımaları ve bedenlerinin değerli ve özel olduğunun farkına varmalarını sağlamaktır. İncelenen kitaplar çocukların bedenlerinin özel ve değerli olduğu vurgusunu yapmakta eksik kalmaktadır.

İncelenen kitapların çok azında cinsel organ isimlerine yer verildiği görülmüştür. Bunlardan birinde cinsel organların anatomik isimlerinin kullanılmaması dikkat çekici bir bulgudur. Cinsel organların anatomik isimlerinin kullanılmamasının olumsuz ve istenmeyen bir durum olduğu söylenebilir. Cinsel organların doğru isimlerini bilmek çocukların cinsel gelişimi ve kendi bedenlerini tanıması için en önemli cinsel eğitim unsurlarından biridir. Çocuklar kitaplardan, yetişkinlerden ya da ulaşabilecekleri kaynaklardan cinsel organların doğru isimleri ile karşılaşmaları kendilerini ifade etmeleri gereken durumlarda önem kazanmaktadır (Acer ve Artan, 2000). Deniz ve Gözütok'un (2017) ve Güzelyurt'un (2020) araştırmalarında da resimli çocuk kitaplarında, cinsel organlara anatomik adı dışında adlar verildiği raporlanmıştır. Cinsel eğitim, küçük yaşlardan itibaren her zaman cinsel organlara doğru adlar verilerek devam ettirilmelidir. Cinsel eğitime ilişkin doğru terminolojiye yer verilmesi gerekmektedir. Doğru adlar kullanılmayıp takma adlara yer verilmesi çocuklar için cinsel eğitimin karmaşık hale gelmesine ve yanlış bilgilerin öğrenilmesine neden olabilir (Deniz ve Gözütok, 2017; Güzelyurt, 2020).

İncelenen resimli çocuk kitaplarında az yer verilen diğer unsurlar sırlar, özel bölgeler, yabancılar, dokunuşlar ve güvenilecek kişilerdir. İyi ve kötü sırların bilinmesi, cinsel eğitimin cinsel istismardan korunma boyutunda incelenen bir unsurudur. Çocuklara iyi ve kötü sırları ve bu sırlar karşısında neler yapmaları gerektiği öğretilmeli ve böylece çocukların kendilerini rahatsız eden sırlar karşısında bunu güvenilecek kişiler listesindeki bir yakınına anlatıp ondan yardım almayı bilmesi gereklidir. Cinsel istismardan korunma boyutunda yapılan çalışmalar incelendiğinde, okul öncesi ve ilkokul öğrencileri ile iyi sır ve kötü sır konularının konuşulmasının çocukların cinsel eğitim ile ilgili bilgi düzeylerini arttırdığı ve cinsel istismardan korunma konusunda daha güçlü hissettiklerini söylemelerini sağladığı görülmektedir (Dereobalı, Karadağ ve Sönmez, 2013; Karakartal, 2020; Kır, 2013).

Çocuklara bedenlerindeki özel bölgeler hakkında bilgi vermek önemlidir. Resimli çocuk kitaplarında erkek-kadın vücutlarının görselleri, özel bölgelerin isimlerinin anatomik isimleri ile özel bölgeler kavramının birlikte verilmesi önemlidir. Özel bölgelere yer veren resimli çocuk kitaplarındaki öykülerle ve özel bölgelerin gizliliği konusunda doğru model olunduğunda çocukların özel bölgeler konusunda bir anlayış kazanması sağlanabilir (Deniz ve Gözütok, 2017).

Çocukların iyi ve kötü dokunuşların neler olduğunu bilmesi cinsel eğitimin tamamlanabilmesi için gerekli unsurlardan birisidir. Yapılan bir araştırmada istismarcıların kandırma, tehdit, zorlama, vaat gibi yöntemlerle çocukları güvende olmadıkları ortamlara getirdikleri belirlenmiştir (Gönültaş, 2016). Resimli çocuk kitaplarında çocuklara yabancıların her türlü istem, kandırma, tehditlerine karşı “HAYIR!" deme vurgusunun yapılması cinsel istismardan korunma boyutunda çocukları güçlü kılacak bir özelliktir (Altundağ, 2020; Katz ve Hamama, 2013). Çocukların kendileri için tehlikede hissettiği durumlarda konuşmak istedikleri kişilerden oluşan bir "güvenilecek kişiler listesi" oluşturması cinsel eğitimin cinsel istismardan korunma boyutunda incelenen bir unsurdur. Her çocuk tehlikede, rahatsız ya da mutsuz hissettiği durumları güvendiği kişilere anlatması gerektiğini öğrenmeli ve bunu uygulamalıdır.

Resimli çocuk kitapları, çocuklara erken yaşlardan itibaren cinsel eğitim vermek amacıyla kullanılabilecek etkili bir eğitsel materyaldir. Cinsel eğitime odaklanan resimli çocuk kitaplarında cinsel eğitim tüm unsurları içeren geniş tanımıyla ele alınarak verilmelidir. Kitaplarda cinsel eğitimin aşamalı verilmesi gereğine bağlı olarak ilk aşama olan beden değeri konusu daha çok işlenmelidir. Cinsel eğitime odaklanan resimli çocuk kitaplarında, sırlar, özel bölgeler, yabancılar, dokunuşlar ve güvenilecek kişiler unsurlarına daha fazla yer verilebilir. Cinsel eğitimin kitaplar yoluyla nitelikli verilebilmesi için cinsel organların anatomik isimlerinin kullanılması önerilmektedir. Resimli çocuk kitaplarında çocukların karşı cinse karşı olan merak duygusunun 
giderilmesi için erkek kadın vücudu farklılıklarına açık ve net şekilde yer verilmesi sağlanabilir. Resimli çocuk kitaplarında cinsel organların anatomik isimlerine yer verilmesi için bu konuya yönelen çocuk kitapları yazarları ve çocuk kitapları editörleri bilinçlendirilebilir. Cinsel eğitim vermek gibi özel amaçla hazırlanan resimli çocuk kitaplarının özenle ve bilimsel yöntemlerle hazırlanarak ailelerin ve öğretmenlerin kullanımına sunulmasının önemli olduğu düşünülmektedir. Elektronik resimli çocuk kitapları yoluyla çocukların, ailelerin ve öğretmenlerin cinsel eğitime kolay erişimleri sağlanabilir. Çocuk kitapları dışında çocuk kanalları, çocuk dergileri, akıllı telefon uygulamaları gibi farklı medya içerikleri hazırlanarak cinsel eğitim verilebilir.

\section{Yazarların Beyanı}

Araştırmacıların katkı oranı beyanı: Araştırmanın giriş, yöntem, bulgular, tartışma ve sonuç bölümlerine ilk yazar $\% 55$, ikinci yazar ise $\% 45$ oranında katkı sağlamıştır.

Etik Kurul Kararı: Araştırma kitaplarla yapılmış olup resimli çocuk kitaplarının cinsel eğitim unsurlarını içerme durumu incelenmiştir. Bu kapsamda insanlar veya hayvanlar üzerinde deney veya veri toplama işlemi yapılmadığı için, etik onay alınmasın gerektiren bir husus mevcut değildir.

Çatışma beyanı: Bu çalışma kapsamında herhangi bir kişi, kurum ya da kuruluşla çıkar çatışması bulunmamaktadır.

Destek ve teşekkür: Araştırmanın yürütülmesinde herhangi bir kurum ya da kuruluştan destek alınmamıştır.

\section{Kaynaklar}

Acer, D. \& Artan, İ. (2000). Üç ve dört yaş grubu çocukların annelerine yöneltmiş oldukları cinsellikle ilgili sorular ve annelerin verdikleri cevapların incelenmesi. Uludă̆ Üniversitesi Eğitim Fakültesi Dergisi, 13(1), 191-204.

Altundağ, S. (2020). Cinsel istismarı önlemede farklı bir yaklaşım: Çocuk farkındalığı, vücuduma dokunma! Ankara Sağllk Bilimleri Dergisi, 9(1), 10-18.

Astuti, B., Sugiyatno, S. \& Aminah, S. (2017). The development of early childhood sex education materials for early childhood education (ECE) teachers. Jurnal Pendidikan dan Pemberdayaan Masyarakat, 4(2), 113-120.

Balter, A. S., Van Rhjin, T. \& Davies, A. (2016). The development of sexuality in childhood in early learning settings: An exploration of Ontario Early Childhood Educators' perceptions. Canadian Journal of Human Sexuality,25(1), 30-40.

Bassey, M. (1999). Case study research in educational settings. England: Open University Press.

Chairilsyah, D. (2019). Sexual education in childhood. International Journal of Educational Best Practices, 3(2), 4151.

Çakşak, A. (2018). Ergenlerde cinsel eğitim. Journal of Institude of Economic Development and Social Researches, 4(11), 498-504.

Çalışandemir, F., Bencik, S. \& Artan, İ. (2008). Çocukların cinsel eğitimi: geçmişten günümüze bir bakış. Eğitim ve Bilim, 33(150), 14-27.

Deniz, Ü. \& Gözütok, A. (2017). Okul öncesi dönem çocuk kitaplarının cinsel gelişim ve cinsel eğitim açısından incelenmesi. Uluslararası Sosyal Araştırmalar Dergisi, 10(49), 424-431.

Deniz, Ü. \& Yıldız Altan, R. (2019). Milli Eğitim Bakanlığı 0-36 aylık çocuklar için eğitim programında cinsel gelişim ve eğitim. Çocuk ve Gelişim Dergisi, 2(3), 34-44.

Dereobalı, N., Karadağ, S. Ç. \& Sönmez, S. (2013). Okul öncesi eğitim öğretmenlerinin çocuk istismarı ihmali şiddet ve eğitimcilerin rolü konusundaki görüssleri. Ege Ĕ̆itim Dergisi, 14(1), 50-66.

Eliküçük, A. \& Sönmez, S. (2011). 6 yaş çocuklarının cinsel gelişim ve eğitimiyle ilgili ebeveyn görüşlerinin incelenmesi. Eğitim-Kültür ve Araştırma Dergisi, 7 (25), 45-62.

Flick, U. (2014). An introduction to qualitative research. New York: Sage. 
Gönültaş, M. B. (2016). Modusoperandi of sexual abusers and their grooming techniques. ZeitschriftfürdieWelt der Türken/Journal of World of Turks, 8(1), 289-305.

Güneş, A. (2018). Adım adım çocuklarda cinsel eğitim. İstanbul: Timaş.

Güzelyurt, T. (2020). Okul öncesi dönemde cinsel eğitim ve cinsel istismardan korunma: Resimli çocuk kitaplarına yönelik bir inceleme. Uluslararası Çocuk Edebiyatı ve Eğitim Araştırmaları Dergisi, 4(1), 54-69.

Işıtan, S. (2016). Özel amaçla yazılmış çocuk kitapları. International Periodical For The Languages Literature and History of Turkish or Turkic, 11(4), 471-492.

İşler, S. (2017). Okul öncesi dönem çocuğu olan ebeveynlerin cinsel gelişime ve cinsel eğitime yönelik bilgi düzeylerinin ve tutumlarının incelenmesi. (Yayımlanmamış Yüksek Lisans Tezi). Eastern Mediterranean University. Gazimağusa, KKTC.

Kairys, S. W., Alexander, R. C., Block R. W., Everett, V. D., Hymel, K. P., Johnson, C. F. \& Bays, J. A. (1999). Guidelines for the evaluation of sexual abuse of children: Subject Review. Pediatrics, 103(1), 186-191.

Kakavoulis, A. (1998) Early childhood sexual development and sex education: A survey of attitudes of nursery school teachers, European Early Childhood Education Research Journal, 6(2), 55-70.

Karakartal, D. (2020). Çocuk cinsel istismarının önlenmesinde cinsel eğitimin önemi. Uluslararası Beşeri Bilimler ve Eğitim Dergisi, 6(13), 145-156.

Kardeş, S., \& Güney Karaman, N. (2018). Okul öncesi eğitim öğretmenlerinin çocuğun cinsel eğitimine ilişkin görüşleri. Abant İzzet Baysal Üniversitesi Eğitim Fakültesi Dergisi, 18(3), 1554-1570.

Katz, C., \& Hamama, L. (2013). Draw me everything that happened to you. Exploring children's drawings of sexual abuse. Children and Youth Services Review, 35(5), 877-882.

Kır, E. (2013). Çocuklara yönelik cinsel taciz ve istismara karşı önleyici eğitim çalışmaları. İstanbul Üniversitesi Hukuk Fakültesi Mecmuası, 71(1). 785-800.

Konur, H. (2006). Dört-altı yaşları arasında çocuğu olan anne-babalara verilen “Cinsel Eğitim Programı”nın cinsel gelişim ve eğitim konusundaki bilgilerine etkisinin incelenmesi. (Yayımlanmamış Yüksek Lisans Tezi). Gazi Üniversitesi: Ankara.

Kurtuncu, M., Utaş Akhan, L. Tanır, İ.M. \& Yıldız, H. (2015). The sexual development and education of preschool children: Knowledge and opinions from doctors and nurses. Sex Disabil, 33 (2), 207-221.

Larrson, I., \& Svedin, C. G. (2002). Teachers' and parents' reports on 3 to 6 year old children's sexual behavior a comparison. Child Abuse \& Neglect, 26(3), 247-266.

Lestari, S. P., Iswanti, D. I., \& Haji, S. (2017). Optimizing sexuality education in early childhood based on "Puppet Show". Health Notions, 1(4), 321-323.

Martin, J., Riazi, H., Firoozi, A. \& Nasiri, M. (2020). A sex education program for teachers of preschool children: A quasi-experimentalstudy in Iran. BMC Public Health, 20(1), 692.

Menmuir, J. \& Kakavoulis, A. (1999). Sexual development and education in early years: A study of attitudes of pre-school staff in Greece and Scotland. Early Child Development and Care, 149 (1), 27-45.

Miles, M. B., \& Huberman, A. M. (2015). Analizde ilk adımlar. (A. Ersoy, Çev.). S. Akbaba, \& A. Ersoy (Çev. Ed.), Nitel veri analizi: Genişletilmiş bir kaynak kitap (2. Baskıdan Çeviri, 1. Baskı) (ss. 50-89) içinde. Ankara: Pegem Akademi Yayıncilık.

Payne, G. \& Payne, J. (2004). Key concepts in social research. London: Sage Publications.

Petty, K. (2001). When young children explore anatomy dilemma or development? Texas Child Care. 19.02.2021 tarihinde http://www.childcarequarterly.com/winter01_story1a.html adresinden erişildi.

Robinson, K. H. \& Davies, C. (2016). Sexuality education in early childhood. (Allen, L. \& Rasmussen, M. L., 
Ed. ) The palgrave handbook of sexuality education, (ss. 217-242) içinde. London, Buckingham: Palgrave Macmillan.

Sargın, N. \& Tor, H. (2002). Türk ve batı kültürlerinde 3-6 yaş çocukları için yazılmış masallarda işlenen cinsel öğeler üzerine bir araştırma. M. Kıbrıs (Ed.), Erken Çocukluk Ĕ̆itimi Kongresi Bildirisi, Ankara.

Sözbilir, M. (2009). Nitel veri analizi. 26.05.2021 tarihinde http://fenitay.files.wordpress.com/2009/02/1112nitelarac59ftc4b1rmada-veri analizi.pdf adresinden erişildi.

Tuğrul, B. \& Artan, İ. (2001). Çocukların cinsel eğitimi ile ilgili anne görüşlerinin incelenmesi. Hacettepe Üniversitesi Ĕ̆itim Fakültesi Dergisi, 20 (20), 141-149.

Tuğut N. \& Gölbaşı Z. (2019). Okul öncesi dönem çocuğu olan (3-6 yaş) ebeveynlerin cinsel eğitim tutumlarının belirlenmesi. Turkish Journal of Family Medicine and Primary Care, 13 (3), 287-294.

Ünal, H. B. (2017). Ebeveyn çocuk ihmal ve istismarı farkındalık ölçeği'nin geliştirilmesi ve uygulanması. (Yüksek Lisans Tezi) Hacettepe Üniversitesi: Ankara.

World Health Organization. (2000). Promotion of sexual health: recommendations for action. Proceedings of The Regional Consultation Convened by Pan American Health Association 2000: 19-22.

World Health Organization. (2006). The World health report 2006: Working together for health. World Health Organization.

Yağan Güder, S. Y. \& Alabay, E. (2018). Children's questions and answers of parents: Sexual education dilemma. International Journal of Progressive Education, 14(6), 138-151.

Yılmaz, M. (2011). Cinsel eğitimde kütüphanelerin rolü. Türk Kütüphaneciliği, 25(1), 8-34. 


\section{EXTENDED ABSTRACT}

\section{Introduction}

Sex education is a process starting in the first years of life with in the family and continuing with the participation of school and other factors in the social environment. The periods between 3 to 6 years of age, also known as early childhood, are critical in sexual development. Martin et al. (2020) determined the elements of sex education to be the principles of sex education, sexual identity, the stages of sexual development and appropriate sex education approaches, children's questions about sexuality, masturbation, and sexual abuse in children. Although conversations about these topics can be difficult in many societies today, it is important to answer the questions children ask in an appropriate, unhurried, natural, and ordinary way. Parents or teachers who lack knowledge about sex education or refrain from discussing it with children are depriving those children of proper sexual development. This, illustrated children's books can play a facilitative role in the provision of sex education in societies where individuals have insufficient information, resources or reluctan to talk about this issue. As a result, the aim of this research is to examine the elements of sex education in children's picture books written for this particular purpose.

\section{Method}

The research was designed with case studies in qualitative research methods, the data were analyzed using content analysis and document examination techniquee. The study group consisted of 30 children's picture books published between 2009 and 2020 and written for the purpose of sex education in early childhood. The purposeful sampling method was used for in-depth research. Data obtained through document examination were analyzed using the content analysis technique. The results of this study were presented as frequency and percentage and expressed with direct quotations. The picture books included in the study were examined by two independent researchers. Codes with consensus and disagreement were determined using the formula proposed by Miles and Huberman (2015) and it was seen that the rate of fitness between coders was $90 \%$. Thus, it was determined that the fitness between the coders was at a good level and the reliability of the data analysis was ensured.

\section{Results}

In this research, 30 children's picture boks were examined in terms of the elements of sexual education included in them. $42.1 \%$ of the examined children's books included illustrations of male and female bodies, $15.9 \%$ included secrets, $11.4 \%$ intimate body parts, $7.8 \%$ foreigners, $7.2 \%$ included reference to genitals, $\% 5.4 \%$ included appropriate/inappropriate touching and people to be trusted, and $4.8 \%$ included body value.

\section{Conclusion}

Sex education is a much broader concept than simply sexuality (World Health Organization, 2006; Martin et al., 2020; Çalışandemir et al., 2008; Güneş, 2018; Kardeş and Güney Karaman, 2018). The fact that the subjects covered in the broad definition of sex education are included in the examined books suggests that picture books are a powerful educational material which can facilitate the work of both families and teachers in the sex education process. Studies show that parents often feel inadequate or uncomfortable to talk to their children about sex education issues (Tuğut \& Gölbaşı, 2019; Tuğrul \& Artan, 2001). It can be said that children's picture books that include sex education elements are a reliable source for parents and teachers with insufficient information. In addition, the feelings of embarrassment and/or shyness in the adult may be relieved by directing the child's interest to these types of books. This study found that most of the books examined included representations of both male and female bodies. Yağan Güder and Alabay (2018) found that children were most curious about topics such as male and female bodies as well as as the pregnancy period. Studies show that sex education should be provided gradually and progressively (Balter, Van Rhijn, \& Davies, 2016; Isler, 2017; Kardes \& Guney Karaman, 2018) and the first step should be the introduction of physical differences in male and female bodies. A fyrther finding of this study was that the subject of body value was the element used least frequently in the picture books examined. Body value is an element of sex education that should develop in parallel with children's understanding of their bodies; Güzelyurt (2020) also 
made similar conclusions. Having the subject of body value included more in children's reference books is important for the progressive nature of sex education. The content related to the differences in the human body should also include an emphasis on the special and valuable bodies of children. It can be said that the examined books are insufficient in emphasizing the body value.

One remarkable finding of this study was that while genitals were included in the examined books, none used the proper anatomical names for these body parts. In studies by Deniz and Gözütok (2017) and Güzelyurt (2020), it was reported that reproductive organs were given names other than their anatomical names in children's picture books. Using nicknames or informal names for these body parts can make sex education more complicated for children and cause them to learn inaccurate information.

Other elements that were rarely included in the picture books examined were secrets, intimate body parts, foreigners, touches and people to be trusted. Considering studies related to protection from sexual abuse, talking to young children about the differences between good secrets and bad secrets is especially important. Sex education plays a role in the prevention of abuse as it increases the child's knowledge what is considered appropriate or inappropriate and makes the child feel empowered and stronger (Karakartal, 2020). Thus, the importance of understanding intimate body parts with their correct anatomical names is critical. It has been stated that children can gain an understanding of intimate body parts if these are included in the children's picture books and if the right model is made for the privacy of intimate body parts (Deniz and Gözütok, 2017). It is also critical for children to know what appropriate and inappropriate touches are. Understanding when to say "no" to advances or deceit from strangers will again empower children in terms of protection from sexual abuse (Altundağ, 2020; Katz \& Hamama, 2013). Finally, it is important that children have a "list of people to trust" consisting of those they can talk to in situations where they feel in danger of sexual abuse. Every child should learn to tell people they trust about situations in which they feel threatened, uncomfortable, or unhappy.

Children's picture books are effective educational materials that can be used to provide sex education from an early age. In children's picture books focusing on sex education, the topic should be handled with a broad definition that includes all elements. It is important to publish children's picture books prepared for special purposes and with appropriate content and to provide them to parents and teachers.

\section{Ek-1: İncelenen Resimli Çocuk Kitaplarının Künye Bilgileri}

\begin{tabular}{lccc}
\hline \multicolumn{1}{c}{ Kitabın Adı } & Kitabın Orijinal Dili & $\begin{array}{c}\text { İlk Baskı } \\
\text { Yılı }\end{array}$ & Yayınevi \\
\hline 1.Bu Vücut Benim! Ben Ne Dersem O Olur! & İngilizce & 2019 & Beyaz Balina \\
\hline 2.Sana Bir Daha Sır Vermeyeceğim! & Türkçe & 2013 & Efil \\
\hline 3.Sır Versem Saklar Mısın? & Katalanca & 2015 & RedhouseKidz \\
\hline 4.Elif Asla Yabancılarla Gitmez & Almanca & 2017 & Türkiye İş Bankası Kültür \\
\hline 5.Kırmızı Çizgi & Arapça & 2017 & Erdem Çocuk \\
\hline 6.Cinsel Eğitim Öyküleri & Türcçe & 2011 & Net Çocuk \\
\hline 7.Bedenim Bana Ait & Almanca & 2014 & Gergedan \\
\hline 8.Ben Nereden Geldim & İspanyolca & 2009 & Altın Kitaplar \\
\hline 9.Kendimizi Tanıoruz Hayır Demeyi Öğreniyoruz & Türkçe & 2018 & Martı Çocuk \\
\hline 10.Bu Beden Benim & Türkçe & 2015 & Mandolin \\
\hline 11.Kendimi Korurum & Türçe & 2017 & Mandolin \\
\hline 12.Annem ile Babamın Yatağı En Rahatı & Türkçe & 2014 & Mandolin \\
\hline 13.Bebekler Nereden Gelir? & İngilizce & 2013 & Tübitak \\
\hline 14.Çağlar Tanımadığı İnsanlarla Bir Yere Gitmez & Almanca & 2011 & Türkiye İş Bankası Kültür \\
\hline 15.İnci Yabancılarla Gitmez & Almanca & 2017 & Türkiye İş Bankası Kültür \\
\hline 16.Kendimi Koruyorum & Türkçe & 2013 & Artemis Çocuk \\
\hline 17.Ben Nasıl Ben Oldum? & İsveçce & 2010 & Dinozor Çocuk \\
\hline 18.Ben Kaybolmam & Türkçe & 2014 & Yeşil Dinozor \\
\hline 19.Yetişkinler Beni İncitiyor & İngilizce & 2011 & İetişim \\
\hline
\end{tabular}


Erken Çocukluk Dönemine Ait Resimli Çocuk Kitaplarında...

\begin{tabular}{lccc}
\hline 20.Veli Nereye Gitti & İngilizce & 2015 & Kuraldış1 \\
\hline 21.Teo'nun "Ben Nereden Geldim?" Kitabı & Türkçe & 2018 & Bilgi \\
\hline 22.Abla Oluyorum & İsveççe & 2017 & Büyülü Fener \\
\hline 23.Ben Kaybolmam Ki & Almanca & 2017 & Gergedan \\
\hline 24.Ben Herkesle Gitmem Ki & Almanca & 2017 & Gergedan \\
\hline 25.Hüso ve Mahremiyet Ĕ̈itimi & Türçe & 2016 & Aydın Psikoloji \\
\hline 26.Annemin Karnında & Fransızca & 2017 & Yapı Kredi Yayınları \\
\hline 27.Ben Kaybolmam Ki & Türkçe & 2017 & Yağmur Çocuk \\
\hline 28.Nele Diyor Ki: Yabancllarla Hiçbir Yere Gitmem & Almanca & 2019 & Çocuk Gezegeni \\
\hline 29.Yabanclar. Kaybolursan Ne Yaparsın? & Türkçe & 2020 & Artemis Çocuk \\
\hline 30.Nasıl Dünyaya Geldik? & Fransızca & 2019 & Timaş Çocuk \\
\hline
\end{tabular}

